\title{
Hazardous Elements in Asbestos Tremolite from the Basilicata Region, Southern Italy: A First Step
}

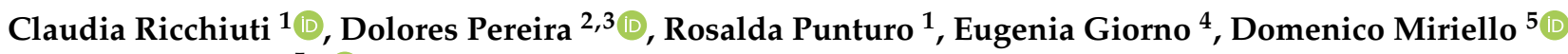 \\ and Andrea Bloise $5, *$ (i) \\ 1 Department of Biological, Geological and Environmental Sciences, University of Catania, 95129 Catania, Italy; \\ claudia.ricchiuti@unict.it (C.R.); punturo@unict.it (R.P.) \\ 2 CHARROCK Research Group, University of Salamanca, Plaza de los Caídos s/n, 37008 Salamanca, Spain; \\ mdp@usal.es \\ 3 Geology Department, Science Faculty, University of Salamanca, Plaza Merced s/n, 37008 Salamanca, Spain \\ 4 MAT-INLAB-Department of Chemistry and Chemical Technologies, University of Calabria, \\ 87036 Rende, CS, Italy; eugenia.giorno@unical.it \\ 5 Department of Biology, Ecology and Earth Sciences (DiBest), University of Calabria, 87036 Rende, CS, Italy; \\ domenico.miriello@unical.it \\ * Correspondence: andrea.bloise@unical.it
}

Citation: Ricchiuti, C.; Pereira, D.; Punturo, R.; Giorno, E.; Miriello, D.; Bloise, A. Hazardous Elements in Asbestos Tremolite from the Basilicata Region, Southern Italy: A First Step Fibers 2021, 9, 47. https://doi.org/ $10.3390 /$ fib 9080047

Academic Editor: Giovanna Rizzo

Received: 18 April 2021

Accepted: 23 July 2021

Published: 1 August 2021

Publisher's Note: MDPI stays neutral with regard to jurisdictional claims in published maps and institutional affiliations.

Copyright: (c) 2021 by the authors. Licensee MDPI, Basel, Switzerland. This article is an open access article distributed under the terms and conditions of the Creative Commons Attribution (CC BY) license (https:// creativecommons.org/licenses/by/ $4.0 /)$.

\begin{abstract}
In this paper, we report the quantification of potentially toxic elements (PTEs) hosted into two tremolite asbestos from Episcopia and San Severino Lucano villages (Basilicata region, Southern Italy). Micro X-ray fluorescence and Inductively Coupled Plasma spectroscopy with Optical Emission Spectrometry techniques were used to quantify the concentration of major, minor ( $\mathrm{Si}, \mathrm{Mg}, \mathrm{Ca}, \mathrm{Al}$, $\mathrm{Fe}, \mathrm{Mn}$ ) and trace elements (As, $\mathrm{Ba}, \mathrm{Cd}, \mathrm{Co}, \mathrm{Cr}, \mathrm{Cu}, \mathrm{Li}, \mathrm{Mo}, \mathrm{Ni}, \mathrm{Pb}, \mathrm{Sb}, \mathrm{Sn} \mathrm{Sr}, \mathrm{Ti}, \mathrm{Te}, \mathrm{V}, \mathrm{W}, \mathrm{Zn}, \mathrm{Zr}$ ), with the aim of providing available data useful for the determination of the asbestos fibers toxicity. Results show that in the two studied samples there exist high concentrations of $\mathrm{Fe}, \mathrm{Mn}, \mathrm{Cr}$ and $\mathrm{Ni}$ which could lead to the high toxicity of the mineral fibers. By considering the pseudo-total PTEs amounts in each tremolite asbestos, it is possible to affirm that one of the samples is more enriched in toxic elements than the other one (3572 ppm versus $1384 \mathrm{ppm}$ ). These PTEs can represent a source of risk to human health since they may be transported away from the geological outcrops, through asbestos in the air, water and soils and thus encountering the human body.
\end{abstract}

Keywords: potentially toxic elements; tremolite asbestos; trace elements; Basilicata region; southern Italy

\section{Introduction}

"Asbestos" is a commercial term that includes six fibrous silicate minerals. The Italian law established that chrysotile, actinolite, tremolite, amosite, anthophyllite and crocidolite were included under the definition of asbestos (i.e., regulated asbestos) [1] Epidemiological studies proved that the development of pathologies, such as malignant mesothelioma and lung cancer, is often linked to occupational or environmental exposure to asbestos [2]. Although many countries have banned the use and marketing of asbestos [3], the environmental exposure of populations still represents an unsolved concern. In addition to asbestos-containing materials (ACMs) that, if not properly handled, release fibers into the atmosphere, the natural occurrence of asbestos (NOA) represents an important source of fibers dispersion. The global territory is interested in the widespread presence of NOA outcrops (e.g., USA, Canada, India, China, Italy, Spain) [4,5] that may be disturbed by natural weathering processes (e.g., erosion) or by human activities (e.g., road construction, excavation, agricultural activities) and release dust containing respirable fibers into the atmosphere [6]. The risks to human health are represented by the potential inhalation of the fibers that become airborne. Depending on their size, the fibers can penetrate deeply into 
the lung alveoli and can no longer be eliminated [7]. Once inhaled, the fibers are in contact with body fluids, which promote their physical-chemical transformation. Depending on parameters such as bio durability and bio persistence, biological reactions may require a shorter or longer time. For instance, it was demonstrated that chrysotile is less bio durable than amphibole asbestos, as well as the retention (bio persistence) of amphiboles in the lung, is higher than chrysotile [8].

To date, it is not completely understood the mechanism by which these fibers induce adverse effects on human health as well as on the environment. Major difficulties in understanding arise from the wide variability of the size, bio durability, molecular arrangement, surface reactivity and chemistry of asbestos fibers [8].

However, it is accepted by the scientific community that, in addition to many other interacting factors, the potentially toxic elements (PTEs) content may contribute to increasing the toxic potential of those fibers which have a high dissolution rate [8]. For instance, Dixon et al. [9] present the results of an in vitro study relating to the effects of chrysotile asbestos and heavy metals on the BP hydroxylase system, supporting the hypothesis that trace metals play an active role in the induction of asbestos cancer while the passive role as the metal carrier is played by asbestos fibers. Moreover, epidemiological studies and experimental evidence, provide indications of the possible onset of lung cancer due to the action of heavy metals [10,11]. Asbestos minerals are capable to host PTEs (i.e., $\mathrm{Fe}, \mathrm{Cr}, \mathrm{Ni}$, $\mathrm{Mn}, \mathrm{Co})[12,13]$, which can be released into the intracellular or extracellular environment during dissolution processes and induce lung cancer [14]. Literature studies, highlighted the importance of the quantification of toxic elements present in asbestos fiber structures since it can be considered an important factor that provides a contribution to the fibers toxicity $[15,16]$. For instance, it was proved that the presence of PTEs increase the risk of developing lung disease in animals and people that have been exposed to asbestos containing large amounts of $\mathrm{Ni}, \mathrm{Cr}, \mathrm{Co}, \mathrm{Cu}$ and $\mathrm{Mn}[9,17,18]$, as well as other research, showed that, even in trace amounts, the presence of $\mathrm{Fe}$ and its structural coordination may induce cyto- and genotoxic effects, thus covering an important role in asbestos toxicity $[19,20]$. Recently Gualtieri [8], proposed a model on asbestos toxicity, based on parameters such as their physical/chemical and morphological characteristics and stating the importance of quantifying the PTEs present within asbestos. Considering that the presence of PTEs within the mineral structure are primary factors for pathological effects, the identification and quantification of PTEs bearing asbestos tremolite in the investigated area are of paramount relevance for modeling the reactivity of such fibers.

In this scenario, for the first time, this work aims to determine the PTEs concentration in tremolite asbestos from the Basilicata region (Southern Italy), using micro X-ray Fluorescence $(\mu-\mathrm{XRF})$ and Inductively Coupled Plasma spectroscopy with Optical Emission Spectrometry (ICP-OES).

\section{Materials and Methods}

In the present study, tremolite asbestos coming from serpentinite rocks cropping out in the surroundings of San Severino Lucano and Episcopia villages (Basilicata region, southern Italy), were investigated. The mineralogical characterization of the tremolite samples has already been carried out by our research group and published elsewhere $[6,21]$. More specifically, TR-EPS comes from the sample E10 [21] and TR-SSL comes from the sample S18 [6]. The sample E10 is characterized by the presence of tremolite and talc [21] whereas sample S18 mainly consists of tremolite and minor chrysotile and chlorite [6].

With the aim of avoiding the possible contamination by other mineral impurities, the collected samples: (i) asbestos tremolite from Episcopia village (sample TR_EPS) and (ii) asbestos tremolite from San Severino Lucano village (sample TR_SSL), were selected using binocular microscopy and then analyzed by $\mu$-XRF and ICP-OES to determine the concentration of major, minor $(\mathrm{Si}, \mathrm{Mg}, \mathrm{Ca}, \mathrm{Fe}, \mathrm{Al}, \mathrm{Mn})$ and trace elements $(\mathrm{As}, \mathrm{Ba}, \mathrm{Cd}$, $\mathrm{Co}, \mathrm{Cr}, \mathrm{Cu}, \mathrm{Li}, \mathrm{Mo}, \mathrm{Ni}, \mathrm{Pb}, \mathrm{Sb}, \mathrm{Sn} \mathrm{Sr}, \mathrm{Ti}, \mathrm{Te}, \mathrm{V}, \mathrm{W}, \mathrm{Zn}, \mathrm{Zr}$ ). It is worth specifying, that even though the manual removal of impurities under the microscope, it is not possible to 
exclude the presence of nano-sized those ones and consequently their small contribution to the chemical composition, if any.

Micro-fluorescence energy dispersion ( $\mu$-XRF) was performed by using a Bruker M4 Tornado spectrometer, equipped with two X-ray tubes ( $\mathrm{Rh}$ and $\mathrm{W}$ ) and two SDD detectors, active area of $60 \mathrm{~mm}^{2}$. The Rh tube has a polycapillary optic to concentrate the radiation in a spot $<20 \mu \mathrm{m}(\mathrm{Mo}-\mathrm{K} \alpha)$. Vacuum conditions ( 2 mbar) were applied for data acquisition, using $\mathrm{Rh}$ radiation with the generator operating at $50 \mathrm{kV}$ and $150 \mu \mathrm{A}$, using two detectors to increase the intensity of the received signal. The acquisition time for each measurement was $60 \mathrm{~s}$. An average of 60 spot analyses were performed on each sample and a double measurement of each point was executed with the aim of improving the element detection. The acquired spectra were processed with the software ESPRIT M4 v. 1.5.2.65 to obtain a semi-quantitative analysis expressed as $\mathrm{wt} \%$ of major elements (oxides) and ppm for traces elements.

Inductively coupled plasma spectroscopy with Optical Emission Spectrometry (ICPOES), Agilent 710 Technology, was used to determine the trace of elements in mineral asbestos fibers.

Using a microwave Milestone MLS Mega 1200 with HPR 1000/10 vessels, $100 \mathrm{mg}$ of powder of sample were dissolved in a mixture of Merck "suprapur" quality acids, nitric acid $(0.5 \mathrm{~mL})$ and hydrofluoric acid $(1.5 \mathrm{~mL})$. After complete dissolution, a small amount of boric acid is added to the composition to neutralize samples before ICP-OES analysis. The calibration curve was prepared using the "multielement smart solutions" for As, B, Ba, Bi, $\mathrm{Cd}, \mathrm{Co}, \mathrm{Cr}, \mathrm{Cu}, \mathrm{Li}, \mathrm{Mo}, \mathrm{Ni}, \mathrm{Pb}, \mathrm{Sb}, \mathrm{Se}, \mathrm{Sn}, \mathrm{Sr}, \mathrm{Ti}, \mathrm{Tl}, \mathrm{V}, \mathrm{W}, \mathrm{Zn}, \mathrm{Zr}$. The instrumental limit of quantification considered (LOQ) for each element was determined with the white method, the values obtained correspond to those provided by the ISO-11885. All the measurements were performed in triplicate to ensure reproducibility.

\section{Results}

\subsection{Major and Minor Elements}

The micro-fluorescence energy-dispersive techniques ( $\mu$-XRF) allowed to measure the concentration of major and minor elements $(\mathrm{Si}, \mathrm{Mg}, \mathrm{Ca}, \mathrm{Fe}, \mathrm{Al}, \mathrm{Mn})$ as oxides, in both tremolite asbestos samples (Figure 1).
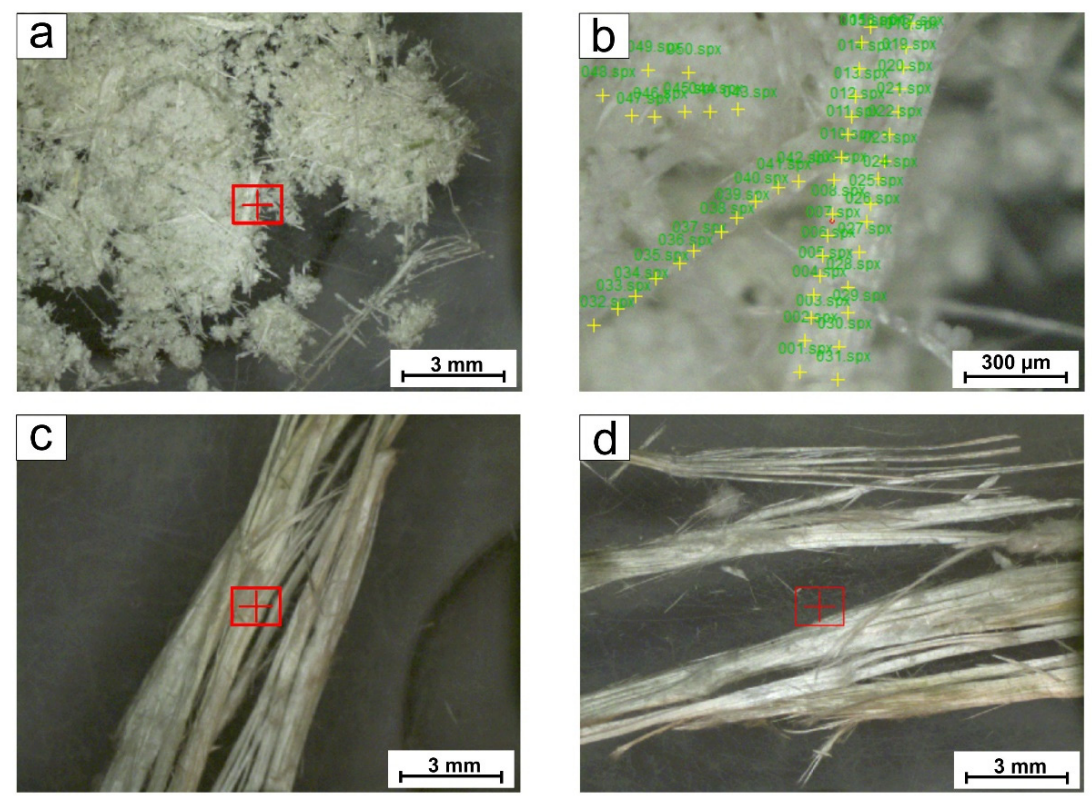

Figure 1. Micro X-ray fluorescence $(\mu-X R F)$ images of: $(\mathbf{a}, \mathbf{b})$ tremolite asbestos from Episcopia village (TR_EPS specimen), crosses are drawn to indicate the analysis points; (c,d) tremolite asbestos from San Severino Lucano village (TR_SSL specimen). 
As for major elements, the data of TR_EPS specimen showed $\mathrm{SiO}_{2}$ and $\mathrm{MgO}$ contents of $53.3 \mathrm{wt} \%$ and $26.0 \mathrm{wt} \%$, respectively, and an amount of $16.8 \mathrm{wt} \%$ for $\mathrm{CaO}$ and $3.3 \mathrm{wt} \%$ for FeO (Figure 2a, Table 1).
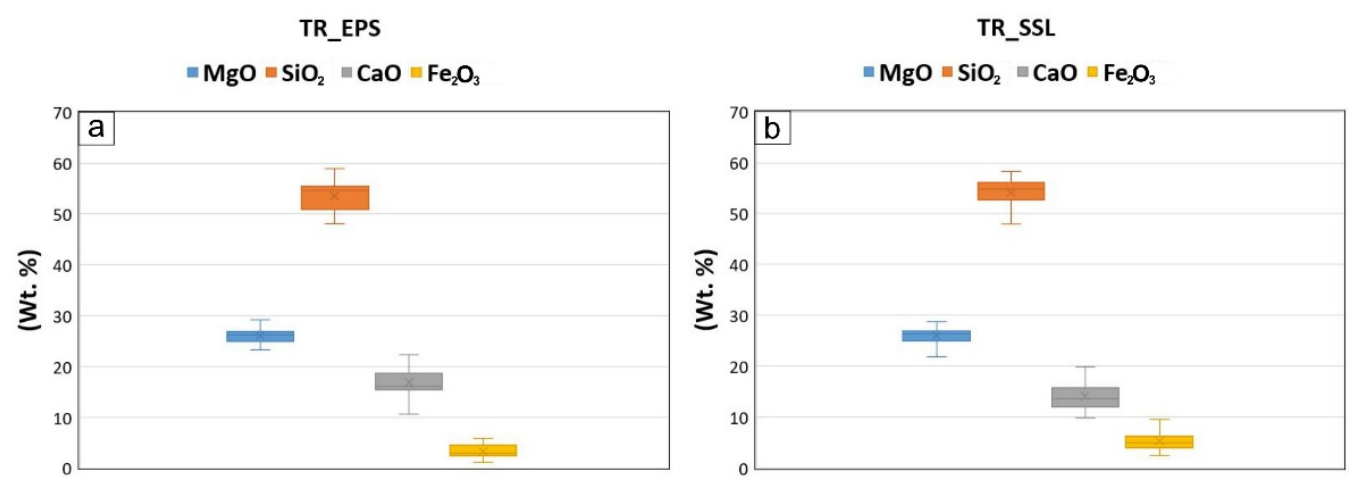

Figure 2. Box plots illustrating statistical parameters for major elements in: (a) tremolite asbestos from Episcopia (TR_EPS); and (b) tremolite asbestos from San Severino Lucano village (TR_SSL). Statistical parameters are based on 60 spot analyses. The range in contents is represented by the vertical lines, the median value is shown by the horizontal line inside the box, the cross indicates the mean values.

Table 1. Average values of major and minor element amounts ( $\mathrm{wt} \%$ ) in the examined tremolite obtained by $\mu$-XRF. TR_EPS = tremolite asbestos from Episcopia; TR_SSL = tremolite asbestos from San Severino Lucano.

\begin{tabular}{ccc}
\hline $\mathbf{( w t} \%)$ & TR_EPS & TR_SSL \\
\hline $\mathrm{MgO}$ & 26.00 & 26.10 \\
$\mathrm{SiO}_{2}$ & 53.32 & 54.12 \\
$\mathrm{CaO}$ & 16.80 & 14.12 \\
$\mathrm{FeO}$ & 3.33 & 5.20 \\
$\mathrm{Al}_{2} \mathrm{O}_{3}$ & 0.32 & 0.35 \\
$\mathrm{MnO}$ & 0.23 & 0.11 \\
\hline
\end{tabular}

Regarding the TR_SSL sample, results revealed $\mathrm{SiO}_{2}$ and $\mathrm{MgO}$ values of $54.1 \mathrm{wt} \%$ and $26.1 \mathrm{wt} \%$ respectively, with a minor amount of $\mathrm{CaO}(14.1 \mathrm{wt} \%)$ and higher content of $\mathrm{FeO}$ (5.2 wt\%) compared to those of TR_EPS (Figure 2b, Table 1). As for minor elements, data showed concentrations of $\mathrm{Mn}$ and $\mathrm{Al}_{2} \mathrm{O}_{3}>1000 \mathrm{ppm}$ in both samples (Table 1). Specifically, the data showed Mn content of $0.23 \mathrm{wt} \%$ in TR_EPS and $0.11 \mathrm{wt} \%$ in TR_SSL and higher values of $\mathrm{Al}_{2} \mathrm{O}_{3}: 0.32 \mathrm{wt} \%$ in TR_EPS and $0.35 \mathrm{wt} \%$ in TR_SSL (Table 1). These results are in agreement with those ones reported by literature, regarding the chemical composition of tremolite asbestos occurring in the surrounding of the study area [22-24].

\subsection{Trace Elements}

The concentrations of trace elements (As, Ba, Cd, Co, Cr, Cu, Li, Mo, Ni, Pb, Sb, Sn, Sr, $\mathrm{Ti}, \mathrm{Te}, \mathrm{V}, \mathrm{W}, \mathrm{Zn}, \mathrm{Zr}$ ) in the two studied samples revealed heterogeneous values (Table 2).

Particular attention was given to some heavy metals such as $\mathrm{Cr}, \mathrm{Ni}, \mathrm{Co}, \mathrm{V}, \mathrm{As}, \mathrm{Ti}$, $\mathrm{Cu}$ and $\mathrm{Zn}$ (Figure 3) since their impact on human health is well known [1,25]. Results revealed that $\mathrm{Cr}$ and $\mathrm{Ni}$ are the elements reaching the highest amounts in both the studied samples.

More specifically, TR_EPS is the sample characterized by a higher concentration of $\mathrm{Cr}(1120 \mathrm{ppm})$ and $\mathrm{Ni}(1830 \mathrm{ppm})$ than TR_SSL, in which the concentrations are $550 \mathrm{ppm}$ (Cr) and $480 \mathrm{ppm}(\mathrm{Ni})$. Similarly, Co and V as well as Ti and Cu show the higher amounts in TR_EPS, while As and Zn are found in higher concentrations in the TR_SSL sample (Figure 3). In particular, the TR_EPS sample showed $31.9 \mathrm{ppm}$ of Co, $6.3 \mathrm{ppm}$ of V, high level of Ti (430 ppm) and $23.2 \mathrm{ppm}$ of $\mathrm{Cu}$, while TR_SSL reveals values of $7.8 \mathrm{ppm}(\mathrm{Co})$, 
$2.6 \mathrm{ppm}(\mathrm{V}), 92.9 \mathrm{ppm}(\mathrm{Ti})$ and $17.8 \mathrm{ppm}$ of $\mathrm{Cu}$. The other heavy metals considered, such as As and Zn, occur in high amounts in the TR_SSL sample: As is present at a concentration of 7.9 ppm in TR_SSL and $3.2 \mathrm{ppm}$ in TR_EPS while $\mathrm{Zn}$ is $37.7 \mathrm{ppm}$ and $34.3 \mathrm{ppm}$ in TR_EPS and TR_SSL respectively. Figure 4 shows the concentration (ppm) levels of the other trace elements detected in the studied samples such as $\mathrm{Ba}, \mathrm{Cd}, \mathrm{Li}, \mathrm{Mo}, \mathrm{Sb}, \mathrm{Sn}, \mathrm{Sr}, \mathrm{Te}, \mathrm{W}$ and $\mathrm{Zr}$.

Table 2. Trace element concentrations (ppm) in the studied tremolite asbestos from Episcopia (TR_EPS) and San Severino Lucano villages (TR_SSL) obtained by ICP-OES.

\begin{tabular}{ccc}
\hline (ppm) & TR_EPS & TR_SSL \\
\hline $\mathrm{As}$ & 3.20 & 7.90 \\
$\mathrm{Ba}$ & 1.10 & 16.50 \\
$\mathrm{Cd}$ & 1.11 & 9.90 \\
$\mathrm{Co}$ & 31.90 & 7.80 \\
$\mathrm{Cr}$ & 1120 & 550 \\
$\mathrm{Cu}$ & 23.20 & 17.80 \\
$\mathrm{Li}$ & 20.50 & 5.30 \\
$\mathrm{Mo}$ & 2.50 & 6.70 \\
$\mathrm{Ni}$ & 1830 & 480 \\
$\mathrm{~Pb}$ & 11.50 & 20.50 \\
$\mathrm{Sb}$ & 15.10 & 11.20 \\
$\mathrm{Sn}$ & 20.50 & 51.70 \\
$\mathrm{Sr}$ & 1.50 & 16.10 \\
$\mathrm{Ti}$ & 430 & 92.90 \\
$\mathrm{Te}$ & 6.40 & 8.80 \\
$\mathrm{~V}$ & 6.30 & 2.60 \\
$\mathrm{~W}$ & 6.30 & 8.80 \\
$\mathrm{Zn}$ & 34.30 & 37.70 \\
$\mathrm{Zr}$ & 7.20 & 32.20 \\
$\mathrm{E}$ TOT & 3573 & 1384 \\
\hline
\end{tabular}
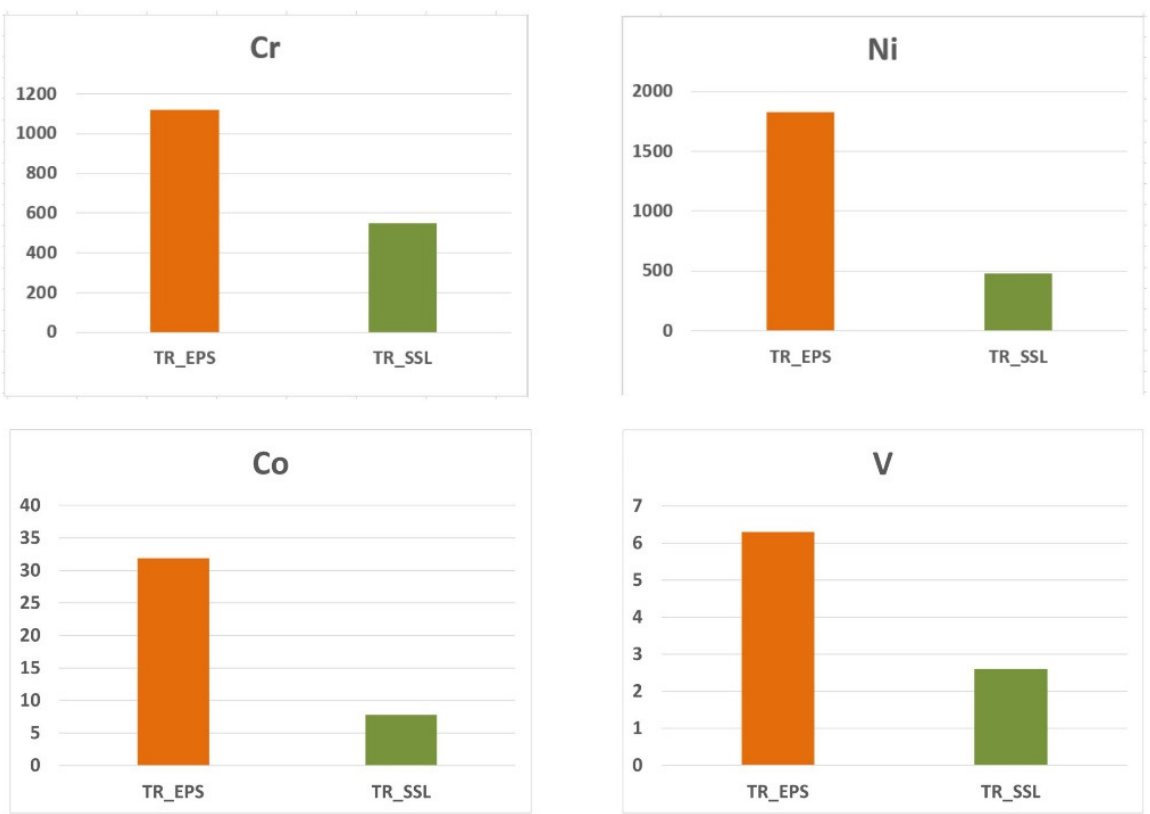

Figure 3. Cont. 


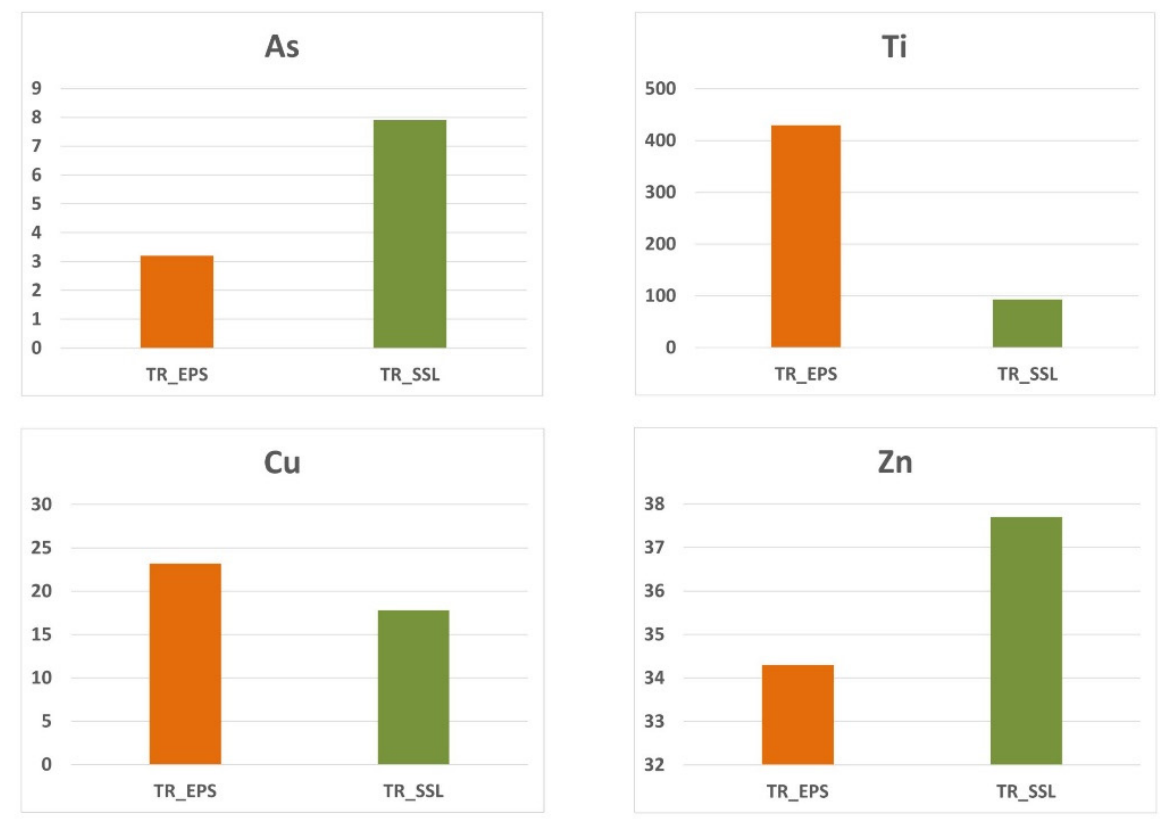

Figure 3. Bar diagrams showing the concentration of some PTEs (heavy metals expressed in ppm) in tremolite asbestos from Episcopia (TR_EPS) and San Severino Lucano (TR_SSL).

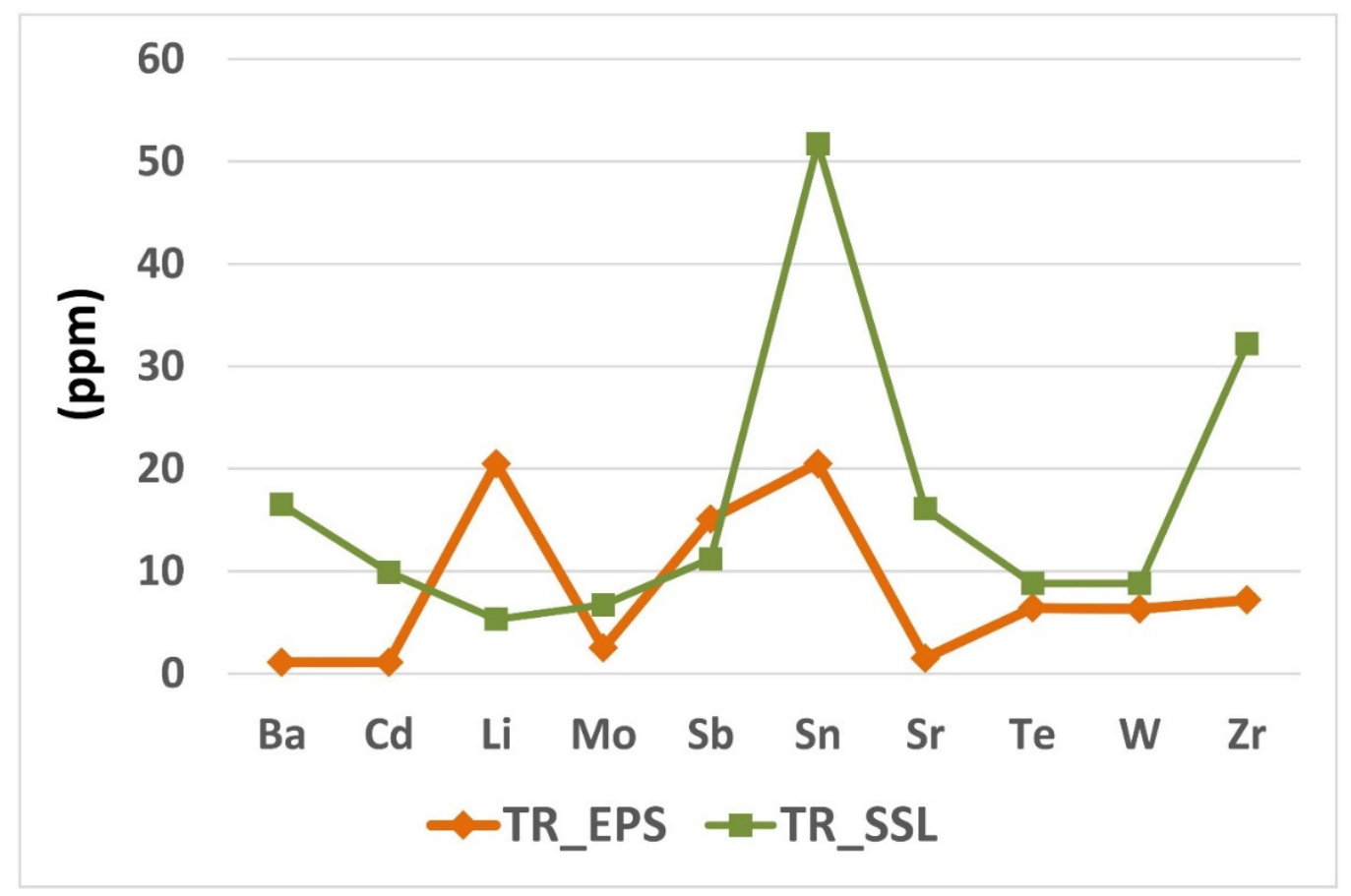

Figure 4. Trace elements concentration (ppm) in tremolite asbestos from Episcopia (TR_EPS) and San Severino Lucano (TR_SSL).

All these elements are present in a higher amount in the TR_SSL rather than TR_EPS sample, except for Li and Sb. Indeed, Ba and Cd in TR_EPS are present at about $1.0 \mathrm{ppm}$, versus $16.5 \mathrm{ppm}$ and about $10 \mathrm{ppm}$ in TR_SSL, respectively, as well as the amount of Sn (20.5 ppm), Sr (1.5 ppm) and $\mathrm{Zr}(7.2 \mathrm{ppm})$ are lower than those ones detected in TR_SSL (51.7 ppm, $16.1 \mathrm{ppm}, 32.2 \mathrm{ppm}$ of $\mathrm{Sn}, \mathrm{Sr}$, and $\mathrm{Zr}$ respectively). However, the difference in $\mathrm{Mo}$, Te and $\mathrm{W}$ concentration amounts between the studied samples is not very obvious. Indeed, Mo values are $2.5 \mathrm{ppm}$ versus $6.7 \mathrm{ppm}$, Te $6.4 \mathrm{ppm}$ versus $8.8 \mathrm{ppm}$ and $6.3 \mathrm{ppm}$ and W 8.8 ppm for TR_EPS and TR_SSL respectively. As for Li and Sb, they were detected 
with higher amounts in TR_EPS showing values of $20.5 \mathrm{ppm}$ and $15.1 \mathrm{ppm}$ respectively versus $5.3 \mathrm{ppm}(\mathrm{Li})$ and $11.2 \mathrm{ppm}(\mathrm{Sb})$ in TR_SSL (Figure 4, Table 2). The concentration levels of all the trace elements detected in the studied samples are reported in Figure 5, in which it is possible to observe the amounts of $\mathrm{Cr}$ and Ni much higher than the other ones.

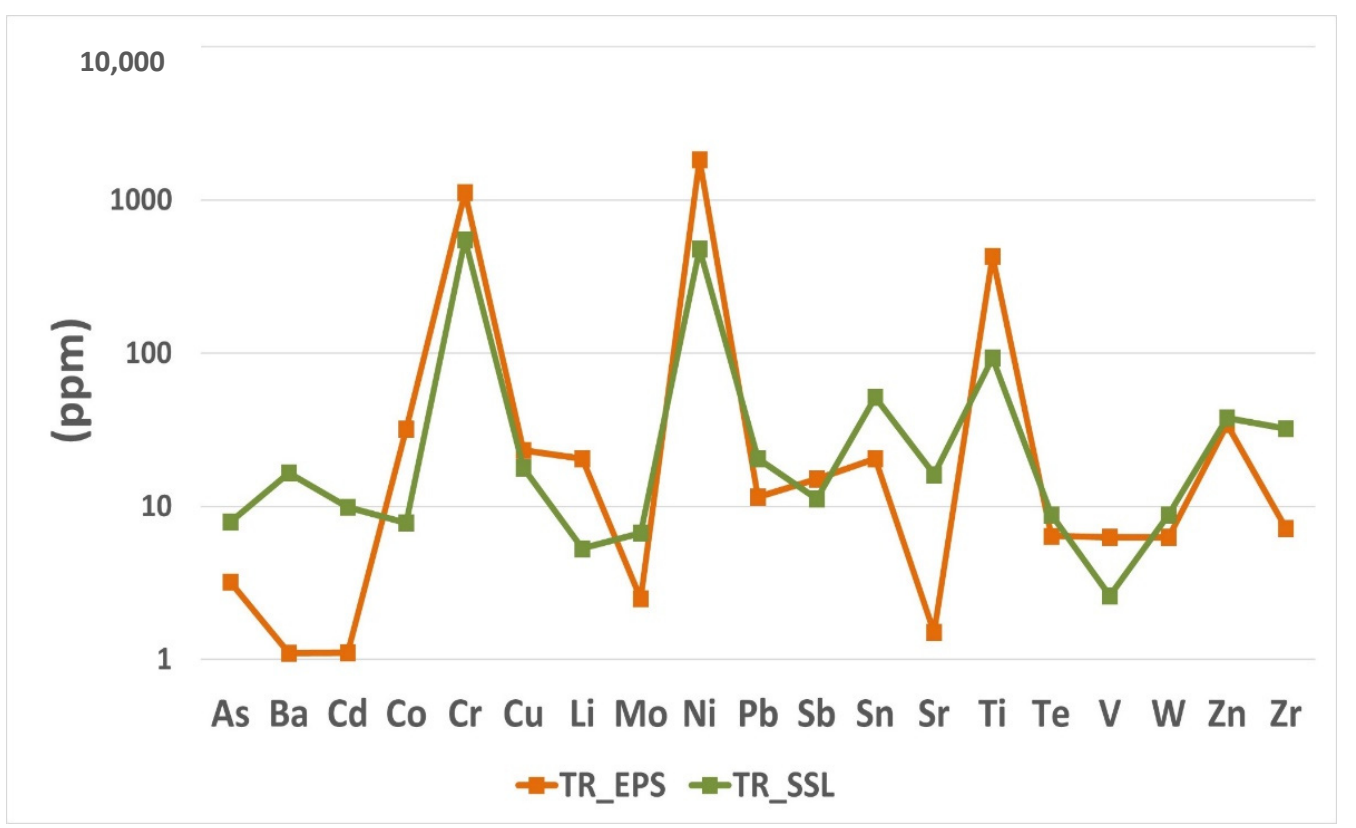

Figure 5. Comparison of trace elements concentration in tremolite asbestos from Episcopia (TR_EPS) and San Severino Lucano (TR_SSL) villages.

\section{Discussion}

\subsection{PTEs in Tremolite Fibers}

Chemical results of the analyzed tremolite asbestos samples from Episcopia (TR_EPS) and San Severino Lucano (TR_SSL) villages in the Basilicata region (southern Italy) revealed a relevant concentration of PTEs. Specifically, among major and minor elements, high values of Fe and Mn, whose role in inducing toxicity is well known [19,20,26,27], stand out in both samples. The presence as well as the structural coordination of $\mathrm{Fe}$, together with surface ferrous ions were considered as important factors in carcinogenicity, because of their ability to catalyse the production of reactive oxygen species (ROS) $[20,26,27]$.

As for Mn, despite it represents an essential nutrient for the human body, an excessive dose can otherwise cause some adverse health effects [28]. Literature studies showed that chronic exposure to high levels of Mn provokes permanent neurological damage, as also observed in former manganese mining workers and smelters [29].

As far as trace elements are concerned, $\mathrm{Cr}$ and $\mathrm{Ni}$ were detected in significant amounts in the studied samples, thus suggesting the high toxicity character of the fibers. Several studies showed that $\mathrm{Cr}$ in the hexavalent redox state is highly toxic and may cause adverse effects on human health [1]; similarly, Ni may induce tumors especially at primary cell cultures, where Ni ions cause significant cellular damage and apoptosis [29,30]. Beyond these two most abundant elements, the high amounts of other heavy metals such as $\mathrm{Co}, \mathrm{V}, \mathrm{Ti}, \mathrm{Cu}$ in TR_EPS and As and Zn in TR_SSL contribute to increasing the toxicity character of the studied samples. For instance, $V$ has the capacity to affect the activities of various intracellular enzyme systems and to the respiratory, circulatory and central nervous systems whereas As may cause the poor functioning of cell respiration as well as that of cell enzymes and mitosis since it primarily affects the sulfhydryl group of cells of the body [31]. By taking into account the many factors affecting the health effects relating to the presence of PTEs in asbestos fibers structure, it may be useful to consider the total balance of PTEs in the studied samples (i.e., $\Sigma$ (As, Ba, Cd, Co, Cr, Cu, Li, Mo, 
$\mathrm{Ni}, \mathrm{Pb}, \mathrm{Sb}, \mathrm{Sn}, \mathrm{Sr}, \mathrm{Ti}, \mathrm{Te}, \mathrm{V}, \mathrm{W}, \mathrm{Zn}, \mathrm{Zr})$ ), which may assist to the toxicity of the different types of tremolite studied in the present work. Indeed, high amounts of heavy metals can contribute to the toxic potential, provided that the fibers are allowed to release their content according to the extent of their dissolution rate. As shown in Figure 6, the TR_EPS specimen is more enriched in PTEs than TR_SSL; therefore, it could be likely assumed that TR_EPS is potentially more dangerous than TR_SSL. In fact, the sum of the PTEs detected in TR_EPS is $3572.61 \mathrm{ppm}$ vs. 1384.4 ppm of TR_SSL (Figure 6, Table 2). As far as the toxic potential of the different types of tremolite is regarded, the presence of high content of heavy metal can contribute, provided that the fibers will be allowed to release their content according to the extent of their dissolution rate. On this basis, the presence of PTEs in asbestos tremolite in the investigated area may constitute a potential risk for human health. Nevertheless, it is worth noting that TR_SSL is highly enriched in Fe (Figure 2b, Table 1), which plays an important role in asbestos-induced cytotoxicity $[19,20]$. These results can be used in the predictive model realized by Gualtieri [8] to obtain the fiber's potential toxicity / pathogenicity index (FPTI). It is worth mentioning, that the combination of various factors such as the dose of the pollutant, the duration of the exposure as well as the various impact of the PTEs on the organism, contribute to the definition of the negative health effects. Indeed, if enough of these elements cumulate into the lungs, because of the fibers dissolution processes, they may provoke the development of cancer (e.g., mesothelioma and bronchogenic carcinoma) [8-11], since they may change the baseline concentrations of these elements in the lungs (Table 3; [32]).

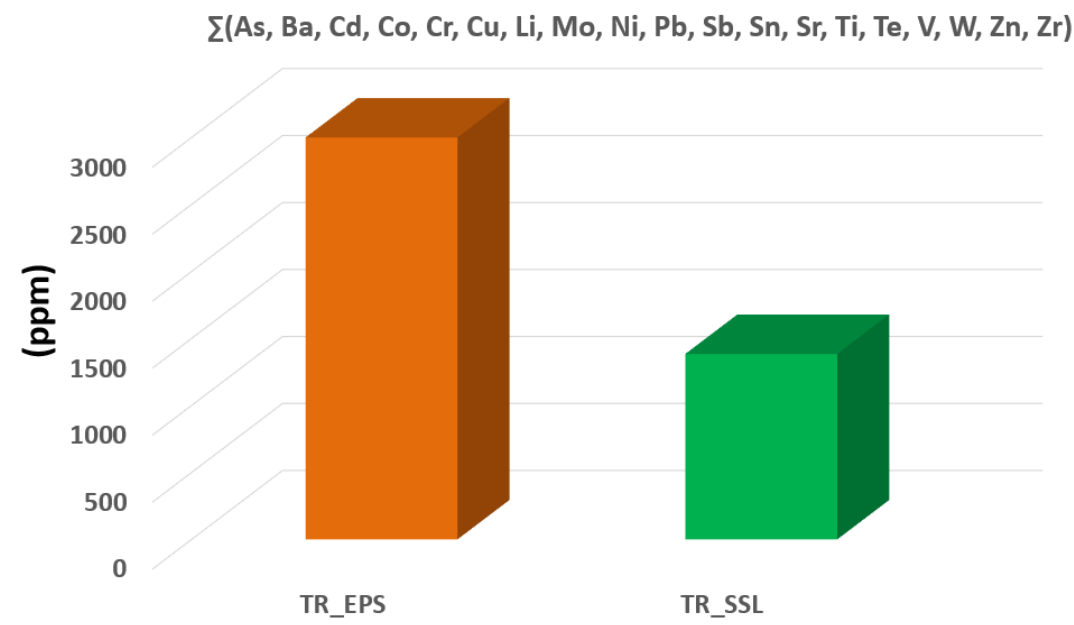

Figure 6. Total trace elements concentration (ppm) in the investigated samples. TR_EPS = tremolite asbestos from Episcopia; TR_SSL = tremolite asbestos from San Severino Lucano.

Table 3. Trace elements (ppm) in the analyzed tremolite asbestos from Episcopia (TR_EPS), San Severino (TR_SSL), and tremolite asbestos from GMRU (TR_GMRU) and Val d'Ala (TR_VLA) studied by Bloise et al. $[15,16]$ showed for comparison. * Indicative baseline data for some trace elements in normal human lung tissues [29].

\begin{tabular}{cccccc}
\hline ppm & TR_EPS & TR_SSL & TR_GMRU & TR_VLA & $\begin{array}{c}\text { Concentration Range in } \\
\text { Human Lungs * }\end{array}$ \\
\hline As & 3.20 & 7.90 & 1.20 & n.d. & $0.001-0.10$ \\
$\mathrm{Ba}$ & 1.10 & 16.50 & 14.80 & 0.61 & $>1.10$ \\
$\mathrm{Co}$ & 31.90 & 7.80 & 22.64 & 26.92 & $0.002-0.10$ \\
$\mathrm{Cr}$ & 1120 & 550 & 170.91 & 165 & $0.002-0.50$ \\
$\mathrm{Cu}$ & 23.20 & 17.80 & 24.53 & 3.23 & $1-5.00$ \\
\hline
\end{tabular}


Table 3. Cont.

\begin{tabular}{cccccc}
\hline ppm & TR_EPS & TR_SSL & TR_GMRU & TR_VLA & $\begin{array}{c}\text { Concentration Range in } \\
\text { Human Lungs * }\end{array}$ \\
\hline $\mathrm{Ni}$ & 1830 & 480 & 308.63 & 473 & $0.01-1.00$ \\
$\mathrm{~Pb}$ & 11.50 & 20.50 & 4.40 & 0.45 & $0.02-0.50$ \\
$\mathrm{Sb}$ & 15.10 & 11.20 & 0.20 & 0.03 & $0.002-0.10$ \\
$\mathrm{Sr}$ & 1.50 & 16.10 & 200 & 6.59 & $0.01-1.00$ \\
$\mathrm{~V}$ & 6.30 & 2.60 & 7.10 & 13.06 & $0.0005-0.50$ \\
$\mathrm{Zn}$ & 34.30 & 37.70 & 28.42 & 17.19 & $1-30.00$ \\
$\sum_{\text {TOT }}$ & 3078.10 & 1168.10 & 782.83 & 706.08 & \\
\hline
\end{tabular}

PTEs can be present in asbestos fibers (i.e., chrysotile and amphiboles) structure as isomorphic substitutions. Moreover, the significant capability of amphiboles for hosting trace elements in octahedral sites (specifically M1, M2, M3) confirms the high amounts of heavy metals detected in the studied samples [12]. For instance, Ni and Co in tremolite likely occupy the specific crystallographic M1 and M3 sites while Cr mainly occupies the M2 site.

\subsection{Environmental Impact of PTEs}

PTEs are usually found in the environment and, in small concentrations, they are needed for maintaining good health; nevertheless, in excessive doses, they can become toxic or hazardous. Indeed, heavy metals can hurt the functioning of organs such as the brain and lungs or affect the blood composition [33-35]. By considering that ophiolite rocks constitute a source of asbestos and widely occur worldwide [5], the quantification of PTEs contained in asbestos fibers is crucial to limit human exposure, especially that one of people living near NOA outcrops. In fact, under specific environmental conditions, potentially toxic elements can be released into the environment, thus constituting a serious hazard for human health. As documented by literature, both areas of Episcopia and San Severino Lucano villages are characterized by a wide occurrence of asbestos $[6,21,36]$, which can become bioavailable and cause the pollution of soils, water as well as the atmosphere. Punturo et al. [36], carried out a multidisciplinary study on serpentinite rocks and derivative soils cropping out in the surroundings of San Severino Lucano, with the aim of determining their bulk chemistry. Results showed, in both rocks and soils, a number of toxic elements (i.e., $\mathrm{Cr}, \mathrm{Co}, \mathrm{Ni}, \mathrm{V}$ ) exceeding the regulatory threshold for public, private and residential green use [Italian Legislative Decree $\mathrm{N}^{\circ} .152$ of 03/04/2006]. Moreover, a significant excess of health problem NOA-correlated cases [2] was verified by epidemiological studies conducted on twelve villages of this part of the region. Specifically, several mesothelioma cases were documented in the area $20 \mathrm{~km}$ far away from Episcopia village and the main cause recognized was the exposure to asbestos minerals [37,38].

Based on the results of this work, the studied samples from Episcopia (TR_EPS) and San Severino Lucano (TR_SSL) villages are characterized by significant amounts of PTEs hosted into asbestos, which may be potentially harmful to humans. The presence of the high amount of these elements in the fiber structure, not only increases the toxicity character of the studied tremolite asbestos but also makes the environmental exposure riskier, due to the occurrence of the mother rock from which they were extracted.

\subsection{PTEs Comparison}

With the aim of observing the difference in PTEs content of tremolite asbestos occurring in another part of the Italian territory, our data were compared to those collected by Bloise et al. $[15,16]$ (Table 3) on tremolite from Gimigliano-Mount Reventino Unit (GMRU; Calabria region, Southern Italy), and tremolite from Val d'Ala (TR_VLA; Piedmont region, Northern Italy) in order to assess, based on the total amount of toxic elements, which one could potentially be more dangerous to human health. As shown in Figure 7, compared to those ones detected by Bloise et al. $[15,16]$, the samples of the present work revealed a 
higher amount of most potentially toxic elements. In particular, $\mathrm{Cr}$ and $\mathrm{Ni}$ values of the samples studied in the present work are much higher than those detected in the other ones, especially in TR_EPS in which their concentration reaches 1120 ppm (Cr) and 1830 ppm (Ni). Moreover, a higher amount of $\mathrm{Co}$ and $\mathrm{Sb}$ characterize TR_EPS whereas tremolite from San Severino Lucano results enriched in $\mathrm{As}, \mathrm{Ba}, \mathrm{Pb}$ and $\mathrm{Zn}$. Differently, TR_GMRU shows a high concentration of $\mathrm{Cu}(24.53 \mathrm{ppm})$ and $\mathrm{Sr}(200 \mathrm{ppm})$ while TR_VLA is more enriched in $\mathrm{V}$ which amount is about $13 \mathrm{ppm}$ (Table 3). By considering the total amount of toxic elements in tremolite asbestos samples (Figure 7), it is possible to assess that TR_EPS is the specimen with the highest amount of PTEs (3078.1 ppm) followed by TR_SSL (1168.1 ppm), TR_GMRU (782.83 ppm) and TR_VLA (706.08 ppm). Therefore, on the basis of the results of the present study and of those conducted by Bloise et al. [20,28], tremolite asbestos from Episcopia and San Severino Lucano are the samples with the highest amount of most PTEs. Therefore, considered equal to the other conditions (e.g., size, duration of exposure), they are potentially toxic to a greater extent. The different concentrations of toxic elements in the tremolite asbestos samples observed, may be due to both the chemical variability of amphiboles and to the geochemical/petrological processes involved in the formation of asbestos fibers $[6,12,16]$.

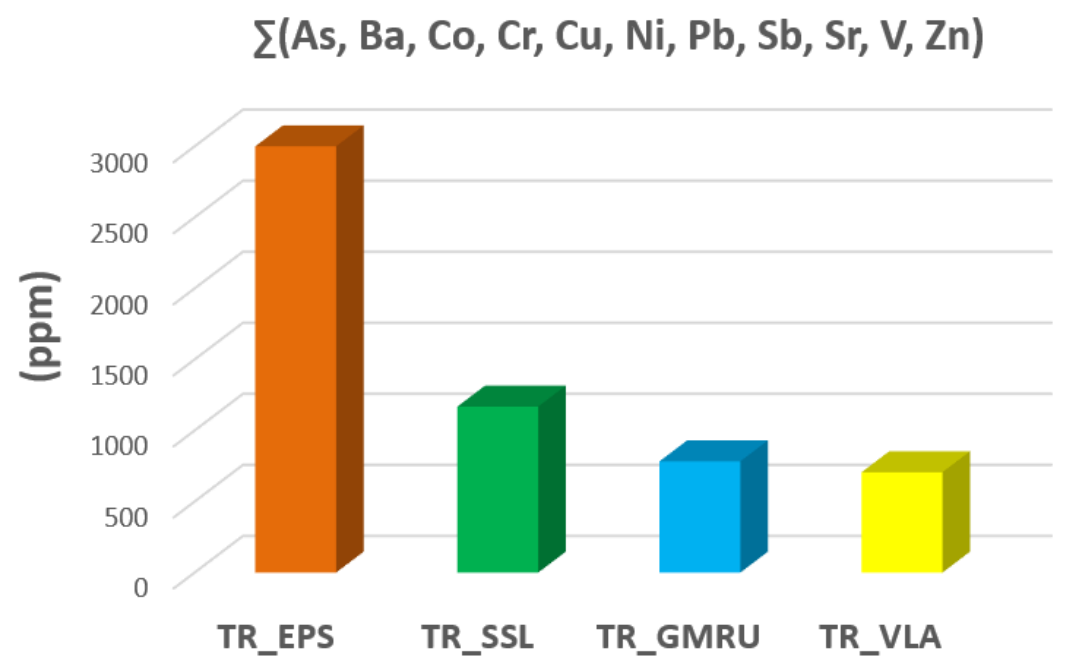

Figure 7. Total amount of trace elements (ppm) in the analyzed tremolite asbestos from Episcopia (TR_EPS), San Severino (TR_SSL), and tremolite asbestos from Gimigliano-Mount Reventino Unit, Calabria (TR_GMRU) and Val d'Ala, Piedmont (TR_VLA) studied by Bloise et al. [15,16] and showed for comparison.

\section{Conclusions}

In the current study, the concentration of PTEs in two different tremolite asbestos samples coming from serpentinite rocks cropping out in the surroundings of Episcopia and San Severino Lucano villages (Basilicata region, Southern Italy) were analyzed. Micro $X$-ray fluorescence $(\mu-\mathrm{XRF})$ and Inductively Coupled Plasma spectroscopy with Optical Emission Spectrometry (ICP-OES) techniques were used to determine the concentration of major, minor ( $\mathrm{Si}, \mathrm{Mg}, \mathrm{Ca}, \mathrm{Al}, \mathrm{Fe}, \mathrm{Mn}$ ) and trace elements ( $\mathrm{As}, \mathrm{Ba}, \mathrm{Cd}, \mathrm{Co}, \mathrm{Cr}, \mathrm{Cu}, \mathrm{Li}, \mathrm{Mo}$, $\mathrm{Ni}, \mathrm{Pb}, \mathrm{Sb}, \mathrm{Sn} \mathrm{Sr}, \mathrm{Ti}, \mathrm{Te}, \mathrm{V}, \mathrm{W}, \mathrm{Zn}, \mathrm{Zr}$ ).

The intrinsic toxicity of asbestos tremolite fibers added to the fact that one of the PTEs results in an extremely dangerous combination for humans and the long-term exposure for the inhabitants of the surrounding areas could derive from the development of different kinds of diseases. The various element concentrations into the two samples allow us to further distinguish them in terms of PTEs amount. High concentrations of trace elements were detected and, by considering the total balance of PTEs in the studied samples ( $\sum$ (As, $\mathrm{Ba}, \mathrm{Cd}, \mathrm{Co}, \mathrm{Cr}, \mathrm{Cu}, \mathrm{Li}, \mathrm{Mo}, \mathrm{Ni}, \mathrm{Pb}, \mathrm{Sb}, \mathrm{Sn}, \mathrm{Sr}, \mathrm{Ti}, \mathrm{Te}, \mathrm{V}, \mathrm{W}, \mathrm{Zn}, \mathrm{Zr}$ )), TR_EPS results to be the asbestos sample with the highest amount of PTEs. The data of our study have general 
implications regarding their possible use to calculate fiber potential toxicity/pathogenicity index (FPTI) which can be a helpful tool for the interpretation of results of in vitro and in vivo testing. Moreover, our study highlights the importance of quantifying PTEs present in asbestos minerals since they increase the toxic character of fibers and can cause lung cancer in humans.

Author Contributions: Conceptualization: A.B., methodology: C.R., A.B., E.G., D.M. and D.P.; formal analysis: A.B., E.G., and D.P.; investigation: A.B., C.R., and R.P.; data curation: A.B., C.R., E.G., D.P. and R.P.; writing—original draft preparation: A.B., C.R., E.G., D.P. and R.P.; writing-review and editing: A.B., C.R., E.G., D.P. and R.P.; visualization: C.R. and A.B.; supervision: A.B.; funding acquisition: A.B., D.P., D.M. and R.P. All authors have read and agreed to the published version of the manuscript.

Funding: This work was supported by the Ministero italiano dell'Università e della Ricerca (MIUR) Progetti di ricercar di interesse nazionale (PRIN) Italy 20173x8WA4. The work has received analytical funding from the research group CHARROCK, at the University of Salamanca (scientific responsible D. Pereira). The work has received financial support from the FFABR Fund (by the Italian MIUR) (scientific responsible A. Bloise). Part of the Research was financed by the University of Catania (Piano di incentive per la Ricerca di Ateneo 2020/2022-Pia.Ce.Ri), Grant Number: 22722132153, within the project: "Combined geomatic and petromatic applications: The new frontier of geoscience investigations from field-to-micro-scale-(GeoPetroMat)".

Institutional Review Board Statement: Not applicable.

Informed Consent Statement: Not applicable.

Data Availability Statement: All the raw data and material used for this research are available at the University of Calabria for request.

Conflicts of Interest: The authors declare no conflict of interest.

\section{References}

1. IARC; Working Group on the Evaluation of Carcinogenic Risk to Humans. IARC Monographs on the Evaluation of Carcinogenic Risks to Humans; No. 100C; International Agency for Research on Cancer: Lyon, France, 2012.

2. Baumann, F.; Buck, B.J.; Metcalf, R.V.; McLaurin, B.T.; Merkler, D.J.; Carbone, M. The presence of asbestos in the natural environment is likely related to mesothelioma in young individuals and women from Southern Nevada. J. Thorac. Oncol. 2015, 10, 731-737. [CrossRef] [PubMed]

3. International Ban Asbestos Secretariat. Available online: http:/ / www.ibasecretariat.org/alpha_ban_list.php (accessed on 15 July 2019).

4. Virta, R. Worldwide Asbestos Supply and Consumption Trends from 1900 through 2003; U.S. Geological Survery: Reston, VA, USA, 2006; p. 80.

5. Ricchiuti, C.; Bloise, A.; Punturo, R. Occurrence of asbestos in soils: State of the Art. Episodes 2020, 43, 881-891. [CrossRef]

6. Bloise, A.; Catalano, M.; Critelli, T.; Apollaro, C.; Miriello, D. Naturally occurring asbestos: Potential for human exposure, san Severino Lucano (Basilicata, southern Italy). Environ. Earth Sci. 2017, 76, 648. [CrossRef]

7. Feder, I.S.; Tischoff, I.; Theile, A.; Schmitz, I.; Merget, R.; Tannapfel, A. The asbestos fibre burden in human lungs: New insights into the chrysotile debate. Eur. Respir. J. 2017, 49, 1602534. [CrossRef] [PubMed]

8. Gualtieri, A.F. Towards a quantitative model to predict the toxicity/pathogenicity potential of mineral fibers. Toxicol. Appl. Pharmacol. 2018, 361, 89-98. [CrossRef]

9. Dixon, J.R.; Lowe, D.B.; Richards, D.E.; Cralley, L.J.; Stokinger, H.E. The role of trace metals in chemical carcinogenesis: Asbestos cancers. Cancer Res. 1970, 30, 1068-1074.

10. Nemery, B. Metal toxicity and the respiratory tract. Eur. Respir. J. 1990, 3, 202-219. [CrossRef]

11. Wei, B.; Yang, L.; Zhu, O.; Yu, J.; Jia, X. Multivariate analysis of trace elements distribution in hair of pleural plaques patients and health group in a rural area from China. Hair Ther. Transplant. 2014, 4, 2167-3118. [CrossRef]

12. Tiepolo, M.; Oberti, R.; Zanetti, A.; Vannucci, R.; Foley, S.F. Trace-element partitioning between amphibole and silicate melt. In Amphiboles: Crystal Chemistry, Occurrence, and Health Issues; Hawthorne, F.C., Oberti, R., Della Ventura, G., Mottana, A., Eds.; Mineralogical Society of America: Chantilly, VA, USA, 2007; Volume 67, pp. 417-452.

13. Vils, F.; Pelletier, L.; Kalt, A.; Muntener, O.; Ludwig, T. The lithium, boron and beryllium content of serpentinized peridotites from ODP Leg 209 (Sites 1272A and 1274A): Implications for lithium and boron budgets of oceanic lithosphere. Geochim. Cosmochim. Acta 2008, 72, 5475-5504. [CrossRef]

14. Bargagli, E.; Monaci, F.; Bianchi, N.; Bucci, C.; Rottoli, P. Analysis of trace elements in bronchoalveolar lavage of patients with diffuse lung diseases. Biol. Trace Elem. Res. 2008, 124, 225-235. [CrossRef] 
15. Bloise, A.; Barca, D.; Gualtieri, A.F.; Pollastri, S.; Belluso, E. Trace elements in hazardous mineral fibres. Environ. Pollut. 2016, 216, 314-323. [CrossRef] [PubMed]

16. Bloise, A.; Ricchiuti, C.; Punturo, R.; Pereira, D. Potentially toxic elements (PTEs) associated with asbestos chrysotile, tremolite and actinolite in the Calabria region (Italy). Chem. Geol. 2020, 558, 119896. [CrossRef]

17. Cralley, L.J.; Keenan, R.G.; Kupel, R.E.; Kinser, R.E.; Lynch, J.R. Characterization and solubility of metals associated with asbestos fibers. Am. Ind. Hyg. Assoc. J. 1968, 29, 569-573. [CrossRef]

18. Schreier, H.; Northcote, T.G.; Hall, K. Trace metals in fish exposed to asbestos rich sediments. Water Air Soil Pollut. 1987, 35, 279-291. [CrossRef]

19. Shukla, A.; Gulumian, M.; Hei, T.K.; Kamp, D.; Rahman, Q.; Mossman, B.T. Multiple roles of oxidants in the pathogenesis of asbestos-induced diseases. Free Radic. Biol. Med. 2003, 34, 1117-1129. [CrossRef]

20. Pacella, A.; Tomatis, M.; Viti, C.; Bloise, A.; Arrizza, L.; Ballirano, P.; Turci, F. Thermal inertization of amphibole asbestos modulates Fe topochemistry and surface reactivity. J. Hazard. Mater. 2020, 398, 123119. [CrossRef] [PubMed]

21. Bloise, A.; Ricchiuti, C.; Giorno, E.; Fuoco, I.; Zumpano, P.; Miriello, D.; Apollaro, C.; Crispini, A.; De Rosa, R.; Punturo, R. Assessment of Naturally Occurring Asbestos in the Area of Episcopia (Lucania, Southern Italy). Fibers 2019, 7, 45. [CrossRef]

22. Dichicco, M.C.; De Bonis, A.; Mongelli, G.; Rizzo, G.; Sinisi, R. $\mu$-Raman spectroscopy and X-ray diffraction of asbestos' minerals for geo-environmental monitoring: The case of the southern Apennines natural sources. Appl. Clay Sci. 2017, 141, 292-299. [CrossRef]

23. Dichicco, M.C.; Laurita, S.; Sinisi, R.; Battiloro, R.; Rizzo, G. Environmental and Health: The Importance of Tremolite Occurence in the Pollino Geopark (Southern Italy). Geosciences 2018, 8, 98. [CrossRef]

24. Dichicco, M.C.; Paternoster, M.; Rizzo, G.; Sinisi, R. Mineralogical Asbestos Assessment in the Southern Apennines (Italy): A Review. Fibers 2019, 7, 24. [CrossRef]

25. IARC. Beryllium, Cadmium, Mercury, and Exposures in the Glass Manufacturing Industry; International Agency for Research on Cancer: Lyon, France, 1993.

26. Fantauzzi, M.; Pacella, A.; Atzei, D.; Gianfagna, A.; Andreozzi, G.B.; Rossi, A. Combined use of X-ray photoelectron and Mossbauer spectroscopic techniques in the analytical characterization of iron oxidation state in amphibole asbestos. Anal. Bioanal. Chem. 2010, 396, 2889. [CrossRef]

27. Liu, G.; Cheresh, P.; Kamp, D.W. Molecular Basis of Asbestos-Induced Lung Disease. Annu. Rev. Pathol. Mech. Dis. 2013, 8, 161-187. [CrossRef] [PubMed]

28. Williams, M.; Todd, G.D.; Roney, N.; Crawford, J.; Coles, C.; McClure, P.R.; Garey, J.D.; Zaccaria, K.; Citra, M. Health Effects. In Toxicological Profile for Manganese; Agency for Toxic Substances and Disease Registry: Atlanta, GA, USA, 2012 ; pp. 39-360.

29. Biedermann, K.A.; Landolph, J.R. Induction of anchorage independence in human diploid foreskin fibroblasts by carcinogenic metal salts. Cancer Res. 1987, 47, 3815-3823.

30. Lee, Y.J.; Lim, S.S.; Baek, B.J.; An, J.M.; Nam, H.S.; Woo, K.M.; Cho, M.K.; Kim, S.H.; Lee, S.H. Nickel (II)-induced nasal epithelial toxicity and oxidative mitochondrial damage. Environ. Toxicol. Pharmacol. 2016, 42, 76-84. [CrossRef] [PubMed]

31. Gordon, J.J.; Quastel, G.H. Effect of organic arsenicals on enzyme system. Biochem. J. 1948, 42, 337-350. [CrossRef] [PubMed]

32. Vanoeteren, C.; Cornelis, R.; Sabbioni, E. Critical Evaluation of Normal Levels of Major and Trace Elements in Human Lung Tissue; Commission of the European Communities: Luxembourg, 1986.

33. Censi, P.; Zuddas, P.; Randazzo, L.A.; Tamburo, E.; Speziale, S.; Cuttitta, A.; Punturo, R.; Aricò, P.; Santagata, R. Source and nature of inhaled atmospheric dust from trace element analyses of human bronchial fluids. Environ. Sci. Technol. 2011, 45, 6262-6267. [CrossRef] [PubMed]

34. Jaishankar, M.; Tseten, T.; Anbalagan, N.; Mathew, B.B.; Beeregowda, K.N. Toxicity, mechanism and health effects of some heavy metals. Interdiscip. Toxicol. 2014, 7, 60-72. [CrossRef] [PubMed]

35. Bloise, A.; Kusiorowski, R.; Lassinantti Gualtieri, M.; Gualtieri, A.F. Thermal behaviour of mineral fibers. In Mineral Fibers: Crystal Chemistry, Chemical-Physical Properties, Biological Interaction and Toxicity; Gualtieri, A.F., Ed.; European Mineralogical Union: London, UK, 2017; Volume 18, pp. 215-252.

36. Punturo, R.; Ricchiuti, C.; Mengel, K.; Apollaro, C.; De Rosa, R.; Bloise, A. Serpentinite-derived soils in southern Italy: Potential for hazardous exposure. J. Mediterr. Earth Sci. 2018, 10, 51-61.

37. Musti, M.; Bruno, C.; Cassano, F.; Caputo, A.; Cauzillo, G.; Cavone, D.; Convertini, L.; De Blasio, A.; De Mei, B.; Marra, M.; et al. Sorve-glianza sanitaria delle popolazioni esposte a fibre di tremolite nel territorio della ASL 3-Lagonegro (PZ). Ann. Dell'istituto Super. Sanità 2006, 42, 469-476.

38. Caputo, A.; De Santis, M.; Manno, V.; Cauzillo, G.; Bruni, B.M.; Palumbo, L.; Conti, S.; Comba, P. Health impact of asbestos fibres naturally occurring in Mount Pollino area (Basilicata Region, Southern Italy). Epidemiol. Prev. 2018, 42, 142-150. 